\title{
The labour pattern as a sociological aspect of agricultural extension work
}

\author{
A. PERK
}

Department of Rural Sociology of Tropical and Sub-Tropical Regions, Agricultural University, Wageningen, Netherlands

\section{Summary}

The purpose of this article is to draw attention to a certain sociological aspect of agricultural extension work, one that is often an important part of the process of providing information in the development areas. The aspect concerned relates to the traditional labour pattern adhered to by a given community.

A number of problems connected with the labour pattern such as the biological division of labour, the nature and extent of the work performed by men and women and the phenomenon of free time or leisure are dealt with in turn.

The last section aims at providing some idea of the practical value which may be distilled from a sound knowledge of local or regional labour patterns.

\section{Introduction}

It is common knowledge that in the last few decades the policy and methods of agricultural extension have undergone a radical change not only in the western areas but also in those development areas where more or less extensive agricultural extension work is being carried out. Until fairly recently it was believed that the task of an agricultural extension service entailed little more than passing on to the farmers by means of demonstrations, model farms, talks, publications, etc. the innovations devised and tested by the experimental stations. The rural population was assumed to possess such economic understanding that it would automatically, as it were, find it in its own best interest to accept the new discoveries. For that reason, the information then provided was purely technical in character, this later being altered to include economic information as well. But this still appeared to be insufficient, and there was continued resistance to farm improvements that were fully justified from the technical and agro-economic points of view. Finally, an attempt was made to trace the possible causes of the reluctance displayed by the farmer and his wife to accept new developments to social factors.

It was found that the farmer had no more than a limited freedom of action within his own community; his actions were to a large extent determined and influenced by the community's traditional patterns of behaviour (HOFSTEE, 1953), these patterns being most clearly discernible in the development areas.

The existence of social barriers obliged the government to devote an increasing amount of attention to the sociological aspects of agricultural extension work. It became apparent that both the methods and the actual information provided would have to be adjusted to the social situation and the cultural pattern of the area concerned if they were to be acceptable to the population.

Received for publication 18th May, 1963. 


\section{The labour pattern}

One of the principal sociological aspects of agricultural extension work which, strangely enough, has received only a limited amount of attention up to the present, is the traditional labour pattern adhered to by the community. The term "labour pattern" is used here to denote the form assumed by the complex of occupational activities carried out within a given community or society. For instance, the work rhythm, the distribution of labour, the division of labour between the sexes and the amount of leisure available may all be regarded as part of the labour pattern.

The more primitive the community, the more rigid the pattern is likely to be. For example, the labour pattern in areas where shifting cultivation is the rule is generally more stable than that found in areas where a superior form of agriculture such as wet rice cultivation has long been the principal agricultural system.

Why is it that the labour pattern is of such importance to the development of native agriculture in the development areas?

It is the general consensus of opinion that the development countries, where $50 \%$ to $80 \%$ of the population is engaged in agriculture, should give priority to agricultural development, this being based on the view that a production surplus in the primary sector is a prerequisite for the development of a national industry (BRAND, 1958). The labour factor is an extremely important part of the agricultural development of such countries since, on the one hand, only modest capital investments can as a rule be made while, on the other hand, a scarcity of land obliges many of them to give priority to increasing their production per hectare. This implies that in many cases a greater investment of labour in agriculture will be the principal means of increasing the production per farmer.

At this point the question arises as to whether the population will be prepared to make the extra effort required and, if so, whether the available labour potential will be sufficient to meet the demand. In order to find the answer it will be necessary to acquire a deeper understanding of the labour pattern current in a given society. This is made especially complicated by the fact that it is subject to considerable fluctuation, varying greatly even from village to village, and because such accurate knowledge can only be obtained by means of a complete analysis. A complete labour analysis of this type includes household activities of all sorts, the preservation of raw materials, the marketing of the produce, home industry, etc.

In such more or less primitive societies, where there is usually no more than a slight differentation of labour, it is likely that the amount of work the farmer and his family have to cope with is more in excess of normal farming activities than is generally supposed. It is therefore by no means certain that the rural population really has as much leisure at its disposal as is usually assumed to be the case. We shall return to this question later.

\section{The division of labour}

The division of labour between the sexes is one of the main elements of the labour pattern. This question has been dealt with by a number of writers, although usually in no more than general terms. VINK (1941) remarked, for instance, that it is almost always based on tradition and physical differences. Heavy manual labour such as clearing forests for shifting cultivation, disposing of the heavy timber afterwards and erecting fences around the fields belongs to the sphere of specifically male activities. 
The tasks which are less demanding physically - tending, harvesting and processing the crops - are usually assigned to the women.

In "Human Types", FIRTH (1958) expresses himself in much the same vein when he states:

In primitive communities hunting, fishing, woodwork, metal-work, and the tending of cattle are more often the tasks of men than women, while looking after the home and children, agriculture and the making of clothing are usually work of the women. Where agriculture is shared the men often have to do the heavier work of breaking up the soil, while the women come in later to tend and weed the plants.

Dube (1955), from whose publications the following extracts are derived, expresses similar views in his study of village life in India.

Division of labour in the community is governed by a variety of factors. Important among them are : caste, sex, age and social status. Caste is an important and rigid determinant of division of labour. Under this system several occupations have been preserved as caste monopolies, while some are "open" and may be adopted by persons belonging to all castes. The factors of sex, age and social status govern the division of labour in nearly all types of work in the community. First, "masculine" and "feminine" pursuits are clearly distinguished: a woman doing man's work is laughed at; a man undertaking any specifically feminine taskes provides a favourite theme for popular gossip. Household work, agricultural activities, traditional craft or occupation of the family, and socio-religious rites and ceremonies are all marked by division of work on basis of sex.

MEAD (1962) displays a similar line of thought, albeit in a more general form, in "Male and Female" while at the same time maintaining that the division of labour, like all cultural elements, is subject to evolution.

The differences between the two sexes is one of the important conditions upon which we have built the many varieties of human culture that give human beings dignity and stature. In every known soctety, mankind has elaborated the biological division of labour into forms often very remotely related to the original biological differences that provided the original clues. Upon the contrast in bodily form and function, men have built analogies between sun and moon, night and day, goodness and devil, strength and tenderness, steadfastness and fickleness, endurance and vulnerability. Sometimes one quality has been assigned to one sex, sometimes to the other.

It may be assumed that in spite of this evolutionary trend, it is extremely difficult to bring about any change in the existing, traditional labour pattern. The following phenomenon affords a typical example. Even in the rural areas of many colonised countries, Western penetration and emancipation introduced a considerable degree of peace and order. One result of this change was that the traditional task of the male, which had largely been directed towards the protection of hearth and home, now became much lighter. In practically all such regions, the men proved to be reluctant to utilize this newly-released labour potential in other fields of activity. Fear of making themselves ridiculous in the eyes of their fellow villagers or tribesmen, which would mean loss of status, seems to be their principal motive for refusing to undertake activities which are traditionally women's work. KouwENHOven (1956) illustrates this theme when he states:

The major task of the man in former days had been to safe-guard his family, do the more strenuous work, and provide meat for the different mouths which had to be fed. Since the pacification of the area the first task of the man had become needless. The introduction of iron tools had often made his other tasks far less strenuous and, consequently, the man was left with more time to kill. 
A little further on he continues:

Yet, the man did not take over a part of the woman's tasks to restore the balance of labour division which was upset by the changed circumstances. This was not to be expected. Van Baal, writing about this phenomenon which is a typical aspect of the contact between Papuan society and Western culture gives an explanation for it. The absence of change in the structure of indigenous society despite the penetration of Western influences did not make it attractive for the Papuan to rearrange the division of labour between the sexes. In case of such a rearrangement the men would lay themselves open to ridicule, the women would be upbraided with laziness.

Such resistance to work regarded as being the sole province of the opposite sex emerges even more clearly from a passage in BRUYNIs' (1933) doctoral thesis dealing with the Marind Anim Papuans in southern New Guinea.

It is reported that many Marind Anim Papuans died unnecessarily during the influenza epidemic of 1918-1919. There was a lack of food because many women were unable to work in the gardens, yet there was no question of the men taking over the women's tasks.

I believe that the above quotations provide a clear enough picture of the rigidity and immobility of a work discipline once it has been absorbed into the culture of a primitive society.

\section{Nature and extent of labour}

Some insight into the nature and extent of the work carried out by men and women in primitive societies would seem to be useful at this point. In spite of the fact that the labour pattern varies considerably from region to region, it is still possible to identify a number of general characteristics in the work alloted to each sex.

The women are usually active in the field of domestic duties, home industry, the lighter type of field work required by the food crops and the processing and marketing of agricultural produce, while the men hunt, fish, take care of the livestock, do the heavy work in the fields and are responsible for the cultivation of cash crops and, to some extent, for the processing and marketing of their agricultural produce.

It should be noted that the women's part in subsistence agriculture can fluctuate heavily from region to region. In some regions, such as extensive areas of Nigeria, it is limited or even very limited, while in others such as New Guinea the women are expected to contribute a relatively large amount of work. It may be stated that within the framework of the whole labour process, the women on the whole make an important contribution to the subsistence agriculture, more especially when the work connected with processing and marketing agricultural products is also classified under the heading of agricultural activities.

Subsistence agriculture is the main agrarian activity in practically all development areas, irrespective of whether cash crops are cultivated on a large scale or not. Labour analyses made in the cocoa region of Nigeria show that even there, where cash crops occupy a prominent place in the agricultural system, the cultivation of food crops still accounts for more than $50 \%$ of the men's working hours and $20 \%$ of those of the women, that is, when the preparation of palm oil and gari (an alcoholic beverage derived from the cassave root) are also included in this work category. It seems that there was no great food shortage among primitive societies in the depression years between 1930 and 1937, a fact that was of course due to these societies having continued to base their agricultural system on food crops in spite of an increasing interest in the production of cash crops for the world market. 
The literature does not provide much exact data on the actual amount of work performed by the family or by men and women in primitive societies.

GALETTI, BALDWIN and DiNA (1956) give a number of tables on the respective work performances of men, women and families and on the nature of their various activities. Although the way in which these data were handled is anything but ideal (the exact description of the type of work carried out leaves much to be desired), some of the surveys of work performances yield interesting information. The following table is a typical example.

Average number of working hours for 187 families in $1951-1952$

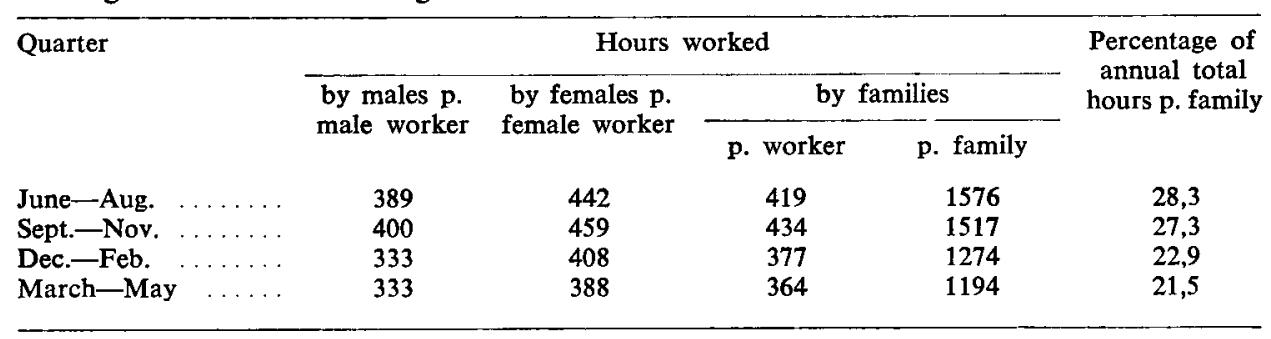

Apart from the fact that labour performance varies rather widely from season to season, as the seasonal nature of agricultural work would lead one to expect, the interesting thing about this table is the indication it gives that the number of hours worked by the women exceeds those of the men in all seasons. This is probably on account of the women's many household duties. Any assumption that the tasks allotted to women in the most primitive communities require longer working hours then those of the men will not be far from the truth. This could mean that the still unrealised labour potential is less for the women than for the men. One consequence of this fact is that where projected economic improvements have to draw on the still untapped labour potenttial of the family, the first appeal will have to de directed towards the men.

These data are in full accordance with Kouwenhoven's contention that the continuing process of pacification has led to the disappearance of part of the male rôle. The difficulty now is to mobilise this released labour potential in some form, to find an outlet acceptable to the men and for which, if possible, they can feel a certain degree of enthusiasm. It is now a typical phenomenon of many development areas that the men are especially interested in the production of cash crops of both the perennial and the annual type. The enormous areas now under rubber, coconuts, cocoa, coffee, etc. are proof of the fact that it should be possible to create a certain impulse towards economic action provided the right methods are employed. Further, it is a notable fact that the extra work thus undertaken by the men has had no disturbing effect on the traditional labour pattern. In other words, they do no work regarded as being specifically women's work; their activities are of an entirely different type.

De Schlippe (1956) states in this context that the men's interest in cash crops does not derive primarily from economic motives but is more attributable to the fact that these crops were introduced by the top group of the hierarchy - the westerners in this instance - and that therefore a certain prestige attaches to them. In addition to the more common cash crops there are yet other prestige crops, such as 
tobacco and sugar cane, which may be regarded as luxury products. A further illustration of the fact that women prefer to adhere to the old, familiar pattern while men are more inclined to orientate their work towards the production of newlyintroduced crops is provided by KRUYT (1924) in his article on the Posso region of the central Celebes. The passage in question reads:

Wet rice cultivation, introduced in 1907, is part of the men's task; dry rice cultivation is carried out by the women.

It may be stated that, broadly speaking, the traditional labour pattern in a number of development areas has been changed to the extent that the newly-released labour potential of the males is largely invested in the cultivation of cash crops and the newly-introduced food crops or, in other words, in the cultivation of crops to which for one reason or another a certain prestige is attached.

\section{Free time or leisure}

To return briefly to the subject of leisure, I remarked in the foregoing that it is doubtful whether the population of development areas actually has much free time at its disposal. For in such primitive societies, where differentiation of labour is either practically non-existent or, at the most, severely limited, almost all of the work connected with agriculture, home industry, the household, etc., will have to be carried out by the actual family concerned. It is to be regretted that the literature on the subject yields so few data which can give us some sort of accurate idea of the amount of leisure at the disposal of the population of any given area. The publication "Nigerian Cocoa Farmers" referred to in the foregoing does give a few tables which provide at least some impression of the extent of such free time.

The following TABLE, for instance, gives the average number of working days for 187 families in the $1951-52$ season, one such day being put at 7 working hours.

Average number of working days in the 1951-52 season (GALETTI, BALDWIN and DinA, 1956 : table 126 , p. 294)

\begin{tabular}{lcccc}
\hline Quarter & & Men & Women & All workers \\
June-Aug. $\ldots \ldots \ldots \ldots$ & 56 & 57 & 63 & 60 \\
Sept._Nov. $\ldots \ldots \ldots$ & 48 & 66 & 62 \\
Dec._Feb. $\ldots \ldots \ldots$ & 48 & 58 & 54 \\
March_-May $\ldots \ldots \ldots$ & 209 & 55 & 52 \\
Year $\ldots \ldots \ldots \ldots \ldots$ & 242 & 228
\end{tabular}

This analysis shows that women work an average of $601 / 2$ days of 7 working hours per quarter and that men work an average of 52 days. Taking a normal number of rest days into account, it appears that the free time per quarter amounts to the equivalent of two weeks for women and three weeks for men. This makes no allowance for time lost through illness, unfavourable weather conditions, religious ceremonies, social obligations etc. The authors comment on the figures as follows :

If we allow fifty-two days in the year for normal rest, there remain only fifty days or one a week, to be accounted for; this is not a great deal of idle time, considering the number of days of bad weather and the length of the slack season.

Production could of course be increased by sacrificing part of this free time or by 
increasing the work tempo, but such a course would require reorientation of the mentality of both the individual and the group and, assuming that no methods involving compulsion are employed, this problem is one for which it is particularly difficult to find a solution. The authors state on p. 295 :

The family's labour could be more fully mobilized but only at the cost of sacrificing leisure and enjoyment which the farmers and their families rate more highly than the possible increase in their income.

In any case, it would seem to be a sensible policy to form a clear idea of the labour pattern in a given region before proceeding to draw up plans for its agricultural development and attempting to put them into practice. I cannot escape the impression that many projected types of farms for development areas are too ambitious because the amount of free time and, consequently, the available labour potential are greatly overestimated.

\section{Practical benefits}

It may be wondered how agricultural extension work can derive any benefit from a close analysis of the labour process. My own experience affords a practical example of a prototype of primitive Papuan community with its shifting cultivation in the former Netherlands New Guinea. In the coastal areas the staple food is sago, and in the hills and mountainous regions tuberous crops. Although no exact figures are available for the labour performance of men and women in agriculture, repeated observation has shown that women have long made an important contribution to the production of food crops, especially in those areas where tuberous crops are grown. It may be assumed that the labour potential of the women, who also have their domestic and other duties to perform, is almost fully utilized.

An agricultural survey combined with a study of the food habits of a community of this type soon reveals the fact that the general standard of nutrition leaves much to be desired, particularly in the inland areas. This somewhat precarious food situation is largely attributable to protein and vitamin deficiencies in the daily diet (Oomen, 1956; Malcolm, 1958). The food situation and, without a doubt, the protein supply is noticeably better in the coastal areas because fish supplies the protein requirements of the local population. It appears from a number of investigations, however, that the deficiencies observed are not entirely due to an insufficient or insufficiently varied diet; they are also attributable to all sorts of persistent diseases. Improved health care alone could effect great changes for the better.

At any rate, the agricultural expert in such a situation will soon show a tendency to concentrate all his attention and ambition on raising the level of production and introducing more differentiation into subsistence agriculture. This usually demands an immediate and fairly considerable extra investment of labour which, in view of the difficulty of effecting any change in the traditional work methods, would mean that the population could scarcely be expected to contribute in other ways to increasing the economic welfare of the community. Furthermore, any extra work required by the subsistence crops is usually turned over to the women, who have often already reached the limits of their working capacity. Experience has in fact shown that any attempt to improve subsistence agriculture in these primitive communities is usually doomed to failure unless it involves no additional labour. The introduction of high-yield or high-grade selections, for instance, may meet with success. 
There is yet another point which must be taken into account when drawing up plans for agricultural extension work. It is a general political aim - almost a political axiom - that the economic development of underdeveloped countries must achieve noteworthy results within a relatively short space of time.

If an agrarian extension policy is drawn up with this object in view, emphasis will often have to be placed on the introduction of cash crops and, in the more or less westernized areas where shifting cultivation is practised, on the perennial cash crops to be cultivated extensively.

The following advantages are attached to the cultivation of perennial cash crops:

a. The cultivation of these crops is easily adapted to the existent agricultural system;

b. The men, who will have to form the principal source of the necessary additional labour, are particularly interested in this category of crops;

c. These new crops have not yet been incorporated into a socio-religious behavioural pattern which could arouse fierce resistance to rational agricultural methods;

d. The amount of labour required by these perennial crops is comparatively small;

e. Perennial crops prevent the erosion and deterioration of the natural fertility of the soil;

f. The cultivation of perennial cash crops leads to a decreased mobility of the population, this being an advantage from the social point of view since it promotes rural education and systematic health care;

g. Both the gross and the net returns per area and per labour unit are generally higher than those from subsistence agriculture.

The most suitable extension work pattern, one that will have to be adapted to the existent static work customs, would seem to be to emphasize the cultivation of perennial cash crops in the first place, and to introduce subsistence crops requiring little or no additional labour that give a higher yield and/or are of better quality than the native crops (VersluYs, 1957; MeAD, 1954; BeagleHole, 1955).

The above observations greatly influenced both the policy and the methods of agricultural extension work followed in the former Netherlands New Guinea and met with a certain measure of success, a claim borne out by the comparatively rapid increase in the cultivation of cash crops in western New Guinea (Anon, 1961).

\section{Conclusion}

The general purpose of this article is to give expression to the fact that the economic development of a particular region or country can be influenced to a considerable extent by local or regional social situations which often lead to what appears to the agricultural expert to be unconquerable opposition. The labour pattern is an important element of the social situation.

Agricultural extension work can only be effective when it is possible to estimate in what way and to what extent the social situation should be altered so as to bring about changes in the economic attitude of the farmer, thus making him more amenable to the introduction of reasonable innovations. 
Anon

Beaglehole, E. BRAND, W.

BruYNIS, N. W.

Dube, S. C.

FIRTH, R.

Galetti, R., K. D. S. BaldWIN and I. O. Dina

HoFsTEE, E. W.

Kouwenhoven, W. J. H.

KRUYT, A. C.

Malcolm, S. H.

Mead, Margaret

OOMEN, H. A. P. C.

SCHLIPPE, P. DE

VINK, G. J.

\section{LITERAT URE}

1961 Report on Netherlands New Guinea for the year 1960 sub. mitted to the United Nations.

1955 Work rhythms. Intern. soc. sci. bull. VII, No. 3, p. 383.

1958 The struggle for a higher standard of living; the problem of the underdeveloped countries. The Free Press, Glencoe, III., U.S.A. and W. van Hoeve Ltd., The Hague and Bandung. $42-43$.

1933 Ethnologische economie en de studie van het economische leven van de inheemsche bevolking in het Oosten van den Indischen Archipel en Nederlandsch Nieuw Guinea. Thesis, Utrecht. p. 107.

1955 Indian Village. Routledge and Kegan Paul Ltd., London. $168-169$.

1958 Human types. The new American Library. 82-83.

1956 Nigerian cocoa farmers. Oxford Univ. Press. Part II, 9 : The factors of production. 287-379.

1953 Sociologische aspecten van de landbouwvoorlichting. Dept. of Social and Economic Geography, Agricultural University Wageningen. Bull. No. 1.

1956 Nimboran; a study of social change and social-economic development in a New Guinea society. Thesis, Leiden. J. N. Voorhoeve, The Hague.

1924 De betekenis van den natten rijstbouw voor de Possoërs. Koloniale Studieën. 1, 33-53.

1958 A study of food intake in two areas of New Guinea. Mimeographed report F.A.O./58/6/4644.

1954 Cultural patterns and technical change. A manual prepared by The World Federation for Mental Health, edited by Margaret Mead, Unesco. p. 296.

1962 Male and female. The new American Library. p. 16.

1956 Poor food patterns in New Guinea. Nieuw Guinea Studiën. 3 , No. 1 .

1956 Shifting cultivation in Africa. Routledge and Kegan Paul Ltd., London. p. 145.

1941 De grondslagen van het Indonesische landbouwbedrijf. Thesis, Wageningen. H. Veenman \& Sons, Wageningen. 